\title{
An Alternative Synthetic Access to cis-4a-Methyloctahydrophenanthrene, a Biomarker of Sergipe-Alagoas Basin Petroleum in Brazil
}

\author{
Denise C. Rodrigues ${ }^{a}$, Armin de Meijere ${ }^{b}$ and Anita J. Marsaioli ${ }^{*, a}$ \\ ${ }^{a}$ Instituto de Química, Universidade Estadual de Campinas, CP 6154, 13083-970 Campinas - SP, Brazil \\ ${ }^{b}$ Institut für Organische Chemie, Georg-August-Universität Göttingen, Tammannstrasse 2, 37077 Göttingen, Germany
}

cis-4a-Metiloctaidrofenantreno (1) foi preparado em 8 etapas (23\% rendimento total) a partir do ácido 2-bromofenilacético (3) e cicloexano-1,3-diona (6). Uma reação de acoplamento do tipo Michael Heck com alta diastereosseletividade cis foi a etapa chave na montagem do esqueleto tricíclico. O composto 1 foi utilizado como padrão cromatográfico o que permitiu identificaçãoinequívoca de um biomarcador minoritário presente no petróleo de Carmópolis, Bacia de SergipeAlagoas, Brasil.

cis-4a-Methyloctahydrophenanthrene (1) was prepared in 8 steps (23\% overall yield) from 2bromophenyl)acetic acid (3) and cyclohexane-1,3-dione (6). A highly cis-diastereoselective Michaeltype Heck coupling served as the key step in the assembly of the tricyclic skeleton. This compound 1 was used as gas chromatography standard which allowed the unequivocal identification of a minor biomarker present in Carmopolis oil from the Sergipe-Alagoas Basin in Brazil.

Keywords: $c i s-4 a$-Methyloctahydrophenanthrene, biomarker, Carmopolis petroleum, SergipeAlagoas Basin

\section{Introduction}

GC/MS analyses of Brazilian petroleum ${ }^{1}$ (Carmopolis oil field, Sergipe-Alagoas Basin, Brazil) disclosed the presence of several acids and hydrocarbons possessing alkylsubstituted monoaromatic sterane, and methyloctahydrophenanthrene (biodegraded monoaromatic sterane) skeletons, most of which require non-commercial standards for full characterization. Confirming the presence of both biomarkers, $\mathbf{1}$ and $\mathbf{2}$, possessing cis A/B-ring configuration, in the studied oils, would provide evidence for the low maturity level of the petroleum and of a common diagenetic precursor for $\mathbf{1}$ and $\mathbf{2}$ (Figure 1). ${ }^{2}$

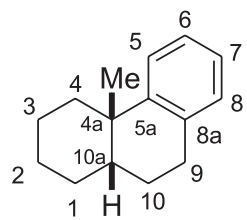

1

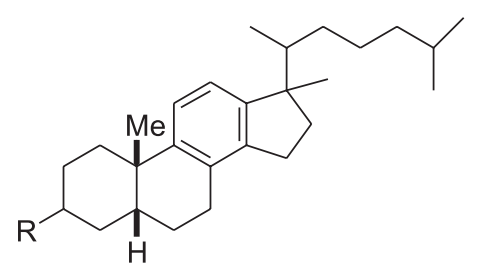

$2 \mathrm{R}=\mathrm{H}, \mathrm{Me}, \mathrm{Et}, n \mathrm{Pr}$
Figure 1. Two biomarkers detected in Brazilian petroleum.

* e-mail: anita@iqm.unicamp.br
Preparation of $c i s-4 a$-methyloctahydrophenanthrene (1) has already been accomplished along several routes. ${ }^{2}$ Notwithstanding these reports we proposed a new synthetic strategy assess cis-diastereomer $\mathbf{1}$ which would easily be extended to the synthesis of $\mathbf{2}$.

\section{Results and Discussion}

The most attractive synthetic strategy based on a retrosynthetic analysis called for the insertion of the arylpalladium bromide intermediate formed from the aryl bromide unit in $\mathbf{9}$ into the tethered cyclohexenone moiety (Scheme 1). This would correspond to the carbopalladation step of an intramolecular Heck reaction, one of the most versatile palladium-catalyzed carbon-carbon bond-forming processes, that has been widely applied for the construction of complex carbon skeletons, ${ }^{3}$ and works particularly well with an electron-acceptor-substituted alkene partner. However, since the intramolecular carbopalladation in $\mathbf{9}$ generates a quaternary center, the intermediate cannot undergo $\beta$-hydride elimination, and must take the course of an overall conjugate addition, as has previously been observed for $\beta$-substituted enones. ${ }^{4}$ According to literature precedence, ${ }^{5}$ cisconfiguration of the formed product could be expected. 
<smiles>O=C(O)Cc1ccccc1Br</smiles>

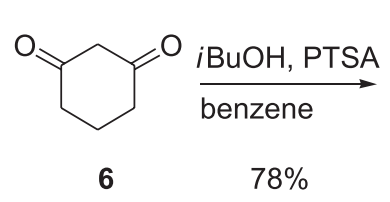<smiles>CCCCOC1=CC(=O)CCC1</smiles>
$78 \%$

1) LDA, DMPU/THF $i \mathrm{BuO}$

2) 5 $59 \%$<smiles>CC1=CC(=O)C(CCc2ccccc2Br)CC1</smiles>

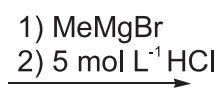

$80 \%$<smiles>CC1=CC(=O)CCC1CCc1ccccc1Br</smiles>

Scheme 1. Synthetic route to the pivotal intermediate 9

The pivotal intermediate $9^{6}$ was easily prepared in three steps from 1,3-cyclohexanedione (6) and 1-bromo-2-(2iodoethyl)benzene (5) in 37\% yield. The latter was obtained from (2-bromophenyl)acetic acid (3) in two steps with 78\% overall yield (Scheme 1).

Applying typical conditions for a Heck reaction (Table 1), i.e. exposing 9 in DMF solution to a mixture of $\mathrm{Pd}(\mathrm{OAc})_{2}$ as catalyst, triphenylphosphine as ligand, tetrabutylammonium bromide as phase transfer catalyst (Jeffery's conditions ${ }^{7}$ ) and methanol/triethylamine as a proton source, at $80^{\circ} \mathrm{C}$ for $12 \mathrm{~h}$, gave a dark mixture, from which, by filtration through a pad of Celite, distribution between diethyl ether and water, and flash chromatography over silica gel of the residue from the ether solution, the cyclization product $\mathbf{1 0}$ was isolated. The yield, which was $36 \%$ in the first attempt (entry 1, Table 1), was only slightly improved by using twice as much $\mathrm{Pd}(\mathrm{OAc})_{2}$ with the same amount of $\mathrm{PPh}_{3}$, yet was significantly higher with a decreased amount of $\mathrm{PPh}_{3}$ or none at all present in the catalyst cocktail (entries 3 and 4).

Careful spectroscopic characterisation of the tricyclic compound $10^{8}$ on the basis of one- and two-dimensional ${ }^{1} \mathrm{H}$ - and ${ }^{13} \mathrm{C}-\mathrm{NMR}$ spectra, revealed that only a single diastereomer had formed, and it was established as the cisfused tricycle $\mathbf{1 0}$ by differential NOE experiments, e. $g$. irradiation at $\delta 0.87$ corresponding to the methyl group on $\mathrm{C}-4 \mathrm{a}$ enhanced the signal of $10 \mathrm{a}-\mathrm{H}(\delta 1.20$ undegassed sample) by $1.5 \%$. From the ketone 10, the target compound $\mathbf{1}^{9}$ was obtained in two steps with $72 \%$ overall yield by transformation to the dithiane $\mathbf{1 1}$ and its reductive desulfurization with Raney nickel (Scheme 2). It is worth mentioning that the desulfurization produced a mixture

Table 1. Optimization of the reaction conditions for the intramolecular Heck-type reaction of compound 9

\begin{tabular}{cccccccc}
\hline Entry & Equiv. of $\mathbf{9}$ & $\mathrm{Pd}(\mathrm{OAc})_{2}(\mathrm{~mol} \%)$ & Ligand & Ligand $(\mathrm{mol} \%)$ & Equiv. $\mathrm{Bu}_{4} \mathrm{NBr}$ & Equiv. Et ${ }_{3} \mathrm{~N}: \mathrm{MeOH}$ & Yield 10 $(\%)$ \\
\hline 1 & 1 & 5 & $\mathrm{PPh}_{3}$ & 20 & 0.4 & $10: 5$ & $36^{\mathrm{a}}$ \\
2 & 1 & 10 & $\mathrm{PPh}_{3}$ & 20 & 0.4 & $10: 5$ & $40^{\mathrm{a}}$ \\
3 & 1 & 10 & $\mathrm{PPh}_{3}$ & 10 & 0.4 & $10: 5$ & $71^{\mathrm{b}}$ \\
4 & 1 & 10 & - & - & 0.4 & $10: 5$ & $85^{\mathrm{b}}$ \\
\hline
\end{tabular}

${ }^{\mathrm{a}}$ Debrominated $\mathbf{9}$ was the major by-product. ${ }^{\mathrm{b}}$ Only traces of debrominated $\mathbf{9}$ were isolated.

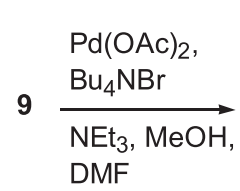

$85 \%$<smiles>CC12CC(=O)CCC1CCc1ccccc12</smiles>

10

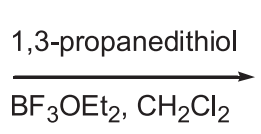

$93 \%$<smiles>CC12CC3(CCC1CCc1ccccc12)SCCCS3</smiles>

11
1-Raney-Ni $\stackrel{2-\mathrm{H}_{2} / \mathrm{Pd} / \mathrm{C}}{\longrightarrow} 1$

$80 \%$

Scheme 2. Transformation of compound 9 into the biomarker $\mathbf{1}$ 
of 1 with other unsaturated hydrocarbons. The crude mixture was hydrogenated, without any attempt to purify its components, to produce almost pure $\mathbf{1}$. In an alternative attempt, 10 was reduced with sodium borohydride to furnish a mixture of equatorial and axial alcohols which could be mesylated, however, reductive removal of the mesyloxy groups by treatment with $\mathrm{LiAlH}_{4}$ failed.

Compound 1 was coinjected with the neutral aromatic fraction from one of the samples from the Carmopolis oil field from Sergipe-Alagoas Basin, Brazil, and it indeed coeluted with one of the components (relative retention index 1617). ${ }^{10}$

\section{Conclusion}

This investigation demonstrates not only the presence of cis-4a-methyloctahydrophenanthrene, biomarker $\mathbf{1}$, in the Carmopolis oil from Sergipe-Alagoas Basin, possessing a cis-decalin moiety, but also that the Michael-type Heck reaction proceeds in high yields and with total cis stereoselectivity during the intramolecular 1,4-conjugate addition of an arylpalladium bromide intermediate to an $\alpha, \beta$-unsaturated ketone with no hydrogen substituent at the $\beta$-position. These results add a new application to the vast repertoire of palladium-catalyzed reactions.

\section{Experimental}

2-(2-Bromophenyl)ethanol (4). To a solution of (2bromophenyl)acetic acid (3) $(0.511 \mathrm{~g}, 2.4 \mathrm{mmol})$ in THF at $0{ }^{\circ} \mathrm{C}$ was added $\mathrm{LiAlH}_{4}(68 \mathrm{mg}, 1.8 \mathrm{mmol})$. The mixture was heated under reflux for $1 \mathrm{~h}$. The reaction mixture was cooled to $0{ }^{\circ} \mathrm{C}$ and treated with $0.5 \mathrm{~mol} \mathrm{~L}^{-1} \mathrm{HCl}(20 \mathrm{~mL})$. The organic fraction was extracted with ether, the combined ethereal solutions were washed with $\mathrm{NaHCO}_{3}$ and brine, dried over $\mathrm{MgSO}_{4}$, and concentrated under reduced pressure furnishing $0.431 \mathrm{~g}(89 \%)$ of the alcohol 4 as a pale yellow oil. ${ }^{1} \mathrm{H} \mathrm{NMR}\left(300 \mathrm{MHz}, \mathrm{CDCl}_{3}\right) \delta 3.03(\mathrm{t}, J 6.9 \mathrm{~Hz}, 2 \mathrm{H})$, 3.89 (t, J 6.9 Hz, 2 H), 7.07-7.13 (m, $1 \mathrm{H}), 7.23-7.29$ (m, 2 $\mathrm{H}), 7.56(\mathrm{~d}, J 8.5 \mathrm{~Hz}, 1 \mathrm{H}) .{ }^{13} \mathrm{C} \mathrm{NMR}\left(75 \mathrm{MHz}, \mathrm{CDCl}_{3}\right) \delta$ $39.3,62.1,124.7,127.5,128.2,131.3,133.0,137.8 . \mathrm{MS}$ (EI) $\mathrm{m} / \mathrm{z}(\%): 202(14)\left[\mathrm{M}^{+}\right], 200$ (14) $\left[\mathrm{M}^{+}\right], 171(50), 169$ (48), 121 (50), 91 (100), 63 (24). IR (film) $v_{\max } / \mathrm{cm}^{-1}: 3367$, 3057, 2939, 2882, 1646, 1567, 1471, 1439, 1156, 1041, $749,659$.

2-(2'-Bromophenyl)iodoethane $(\mathbf{5})$. To a solution of the alcohol 4 (0.148 g, $0.74 \mathrm{mmol})$, triphenylphosphine (0.340 $\mathrm{g}, 1.30 \mathrm{mmol})$, and imidazol $(0.092 \mathrm{~g}, 1.35 \mathrm{mmol})$ in ether/ acetonitrile $(20 / 10 \mathrm{~mL}) \mathrm{kept}$ at $0{ }^{\circ} \mathrm{C}$ was added iodine $(0.380 \mathrm{~g}, 1.5 \mathrm{mmol})$ with stirring. After $30 \mathrm{~min}$ the reaction was complete. The organic fraction was extracted with ether, and the ethereal solution washed with saturated $\mathrm{Na}_{2} \mathrm{SO}_{3}$ solution and brine, dried over $\mathrm{MgSO}_{4}$ and distilled under pressure furnishing $0.203 \mathrm{~g}(88 \%)$ of the iodide $\mathbf{5}$ as a colorless oil. ${ }^{1} \mathrm{H}$ NMR $\left(300 \mathrm{MHz}, \mathrm{CDCl}_{3}\right) \delta$ 3.27-3.40 (m, $4 \mathrm{H}), 7.11-7.16(\mathrm{~m}, 1 \mathrm{H}), 7.22-7.30(\mathrm{~m}, 2 \mathrm{H}), 7.55$ (d, $J$ $8.0 \mathrm{~Hz}, 1 \mathrm{H}) .{ }^{13} \mathrm{C} \mathrm{NMR}\left(75 \mathrm{MHz}, \mathrm{CDCl}_{3}\right) \delta 3.2,40.6,124.1$, 127.6, 128.6, 130.7, 133.1, 139.8. MS (EI) $\mathrm{m} / z(\%): 312$ (4) $\left[\mathrm{M}^{+}\right], 310(4)\left[\mathrm{M}^{+\cdot}\right], 185$ (77), 183 (75), 104 (100), 77 (62), 51 (29). IR (film) $v_{\max } / \mathrm{m}^{-1}: 3055,2959,2856,1567,1469$, 1440, 1235, 1173, 1087, 1046, 1025, 942, 904, 750, 723, $658,619,532$.

3-Isobutoxycyclohex-2-en-1-one (7). Into a two-neck round-bottomed flask connected to a Dean-Stark apparatus, containing 1,3-cyclohexanedione (3.887 g, $34.7 \mathrm{mmol}$ ) and $p$-toluenesulfonic acid monohydrate $(0.275 \mathrm{~g}, 1.4$ mmol), was added benzene $(80 \mathrm{~mL})$ and isobutyl alcohol (30 $\mathrm{mL}, 324 \mathrm{mmol}$ ). The mixture was heated so that the azeotrope started to distill off. After all the water had been removed by azeotropic distillation, the reaction mixture was cooled down to room temperature, washed with $5 \%$ $\mathrm{KOH}$ solution, water and brine, dried over $\mathrm{MgSO}_{4}$. Distillation under reduced pressure furnished $4.52 \mathrm{~g} \mathrm{(78 \% )}$ of compound 7 as a colorless oil. ${ }^{1} \mathrm{H}$ NMR $(500 \mathrm{MHz}$, $\left.\mathrm{CDCl}_{3}\right) \delta 0.98(\mathrm{~d}, J 6.5 \mathrm{~Hz}, 6 \mathrm{H}), 1.96-2.08(\mathrm{~m}, 3 \mathrm{H}), 2.33(\mathrm{t}$, $J 7.0 \mathrm{~Hz}, 2 \mathrm{H}), 2.43(\mathrm{t}, J 6.5 \mathrm{~Hz}, 2 \mathrm{H}), 3.60(\mathrm{~d}, J 6.5 \mathrm{~Hz}, 2 \mathrm{H})$, $5.33(\mathrm{~s}, 1 \mathrm{H}) .{ }^{13} \mathrm{C} \mathrm{NMR}\left(75 \mathrm{MHz}, \mathrm{CDCl}_{3}\right) \delta 19.1,21.1,27.6$, 28.7, 36.3, 73.9, 102.7, 175.0, 195.2. MS (EI) $\mathrm{m} / z(\%): 168$ (3) $\left[\mathrm{M}^{+\cdot}\right], 113$ (64), 84 (100), 69 (18), 57 (68), 41 (73). IR (film) $v_{\max } / \mathrm{cm}^{-1}: 2960,2875,1651,1606,1476,1384$, 1329, 1223, 1185, 1136, 1006, 955, 865, 823, 760, 606.

6-[2'-(2"-Bromophenyl)ethyl]-3-isobutoxycyclohexen2-en-1-one (8). To a solution of diisopropylamine $(0.17$ $\mathrm{mL}, 1.2 \mathrm{mmol})$ in THF ( $5 \mathrm{~mL}$ ) kept under argon at $-20{ }^{\circ} \mathrm{C}$, was added $n$-butyllithium $(1.2 \mathrm{mmol})$. The mixture was stirred for $1 \mathrm{~h}$, cooled down to $-78{ }^{\circ} \mathrm{C}$, and 3 isobutoxycyclohex-2-en-1-one (7) (0.205 g, $1.2 \mathrm{mmol}$ ) was added via syringe. The enolate solution was stirred for 20 min, and $0.6 \mathrm{~mL}$ of DMPU was added. The reaction mixture was stirred for an additional $40 \mathrm{~min}$, and $2-\left(2^{2}-\right.$ bromophenyl)iodoethane (5) (0.268 g, $0.86 \mathrm{mmol}$ in $3 \mathrm{~mL}$ of THF) was added slowly. The mixture was warmed to room temperature. The organic fraction was extracted with ether, the ethereal solution was washed with water and brine, dried over $\mathrm{MgSO}_{4}$ and concentrated under reduced pressure. Purification by chromatography on silica gel afforded $0.177 \mathrm{~g}(59 \%)$ of the enone $\mathbf{8}$ as a colorless oil. ${ }^{1} \mathrm{H}$ NMR (500 MHz, $\left.\mathrm{CDCl}_{3}\right) \delta 0.97(\mathrm{~d}, J 7.0 \mathrm{~Hz}, 6 \mathrm{H}), 1.65-$ 1.73 (m, $1 \mathrm{H}), 1.81-1.88$ (m, $1 \mathrm{H}), 1.97-2.07$ (m, $1 \mathrm{H})$, 
2.12-2.21 (m, 2 H), 2.24-2.30 (m, 1 H), 2.42-2.52 (m, 2 H), 2.78 (ddd, $J 13.5,10.5$ and $5.5 \mathrm{~Hz}, 1 \mathrm{H}$ ), 2.86 (ddd, $J$ $13.5,11.0$ and $5.5 \mathrm{~Hz}, 1 \mathrm{H}), 3.59$ (dd, $J 6.3$ and $1.5 \mathrm{~Hz}, 2 \mathrm{H}$ ), $5.32(\mathrm{~s}, 1 \mathrm{H}), 7.04(\mathrm{td}, J 7.5$ and $1.5 \mathrm{~Hz}, 1 \mathrm{H}), 7.23(\mathrm{td}, J 7.5$ and $1.5 \mathrm{~Hz}, 1 \mathrm{H}), 7.29$ (dd, J 7.5 and $1.5 \mathrm{~Hz}, 1 \mathrm{H}), 7.51$ (dd, $J 7.5$ and $1.5 \mathrm{~Hz}, 1 \mathrm{H}) .{ }^{13} \mathrm{C} \mathrm{NMR}\left(125 \mathrm{MHz}, \mathrm{CDCl}_{3}\right) \delta 19.1$, 26.4, 27.7, 28.0, 30.0, 33.6, 44.8, 74.8, 102.3, 124.4, 127.5, 127.6, 130.5, 132.7, 141.5, 177.0, 201.1. HRMS (EI) $\mathrm{m} / \mathrm{z}$ (\%): $271.2072(15)\left[\mathrm{M}^{+\bullet}-\mathrm{Br}\right] ; 215.1355$ (6); 168.1340 (100); 112.0634 (96); 84.0678 (6); 57.0727 (9). IR (film) $v_{\max } / \mathrm{cm}^{-1}: 3031,2958,2933,2872,1654,1608,1496$, $1471,1545,1384,1368,1223,1195,1178,994,833,752$, 699.

4-[2'-(2"-Bromophenyl)ethyl]-3-methylcyclohex-2-en1-one (9). To a solution of compound 8 (0.108 g, $0.31 \mathrm{mmol})$ in THF $(10 \mathrm{~mL})$, kept under argon at $0{ }^{\circ} \mathrm{C}$, was added methylmagnesium bromide $(0.5 \mathrm{mmol})$. After 30 min no more starting material was detected by TLC. The reaction mixture was treated with saturated $\mathrm{NH}_{4} \mathrm{Cl}$ solution $(10 \mathrm{~mL})$, and the organic phase was extracted with ether $(2 \times 15 \mathrm{~mL})$. After separation of the phases, $2 \mathrm{~mol} \mathrm{~L}^{-1} \mathrm{HCl}(20 \mathrm{~mL})$ was added to the organic fraction, and the biphasic mixture was stirred overnight. Afterwards the organic phase was washed with saturated $\mathrm{Na}_{2} \mathrm{CO}_{3}$ solution, water and brine, dried over $\mathrm{MgSO}_{4}$ and concentrated under reduced pressure. Purification by chromatography on silica gel afforded $0.072 \mathrm{~g}(80 \%)$ of compound 9 as a colorless oil. ${ }^{1} \mathrm{H} \mathrm{NMR}\left(300 \mathrm{MHz}, \mathrm{CDCl}_{3}\right)$ $\delta 1.68-1.82(\mathrm{~m}, 1 \mathrm{H}), 1.86-1.96(\mathrm{~m}, 1 \mathrm{H}), 1.97$ (d, J $1.1 \mathrm{~Hz}$, $3 \mathrm{H}), 2.01-2.21$ (m, 2 H), 2.29-2.39 (m, 2 H), 2.53 (ddd, $J$ 16.8, 11.2 and $5.5 \mathrm{~Hz}, 1 \mathrm{H}$ ), 2.73 (ddd, $J 13.2,10.9$ and 5.8 $\mathrm{Hz}, 1 \mathrm{H}), 2.93$ (ddd, $J 13.2,11.2$ and $5.1 \mathrm{~Hz}, 1 \mathrm{H}), 5.85$ (s, 1 H), 7.06-7.11 (m, 1 H), 7.22-7.29 (m, 2 H), 7.54 (d, J 7.7 $\mathrm{Hz}, 1 \mathrm{H}) .{ }^{13} \mathrm{C} \mathrm{NMR}\left(75 \mathrm{MHz}, \mathrm{CDCl}_{3}\right) \delta 23.0,26.1,31.1$, 33.8, 34.7, 39.4, 124.6, 127.1, 127.9, 128.2, 130.6, 133.3, 141.2, 165.8, 200.0. HRMS (EI) $\mathrm{m} / \mathrm{z}(\%): 294.0432$ (2), 292.0463 (2) [292.04628 Calcd. for $\mathrm{C}_{15} \mathrm{H}_{17} \mathrm{BrO}, \mathrm{M}^{+}$], 279.0227 (4), 277.0252 (5), 213.1254 (6), 183.9665 (82), 181.9686 (84), 123.0737 (11), 95.0425 (100), 67.0457 (10). IR (film) $v_{\max } / \mathrm{cm}^{-1}: 3026,2943,2864,1668,1625$.

4a-Methyl-1,2,3,4,4a,9,10,10a-octahydrophenanthren-3-one (10). In a two-neck round-bottomed flask was added under argon palladium acetate $(9.2 \mathrm{mg}$, $0.041 \mathrm{mmol})$, triphenylphosphine (10.8 mg, $0.041 \mathrm{mmol})$, tetrabutylammonium bromide $(52 \mathrm{mg}, 0.16 \mathrm{mmol})$, triethylamine $(0.6 \mathrm{~mL}, 4.3 \mathrm{mmol})$ and anhydrous DMF (5 $\mathrm{mL})$. Argon was bubbled through the solution for $5 \mathrm{~min}$ which turned orange-brown. $\mathrm{MeOH}(0.1 \mathrm{~mL}, 2.4 \mathrm{mmol})$ and compound 9 (120 mg, $0.41 \mathrm{mmol}$, predissolved in 2
$\mathrm{mL}$ of DMF) was added to the mixture. Argon was bubbled through the solution for an additional $5 \mathrm{~min}$. The mixture was heated to $80^{\circ} \mathrm{C}$ and stirred at this temperature for $16 \mathrm{~h}$. After this period the reaction mixture was cooled down to room temperature and filtered through a pad of Celite. The organic fraction was extracted with ether, and the ethereal solution washed with water, dried over $\mathrm{MgSO}_{4}$ and concentrated under reduced pressure. Purification by chromatography on silica gel afforded $62 \mathrm{mg}(71 \%)$ of compound 10 as a colorless solid. ${ }^{1} \mathrm{H}$ NMR $(500 \mathrm{MHz}$, $\left.\mathrm{C}_{6} \mathrm{D}_{6}\right) \delta 0.87(\mathrm{~s}, 3 \mathrm{H}), 1.08-1.15(\mathrm{~m}, 1 \mathrm{H}), 1.17-1.22(\mathrm{~m}, 1$ $\mathrm{H}), 1.26-1.31$ (m, $2 \mathrm{H}), 1.35-1.42$ (m, $1 \mathrm{H}), 1.71-1.80$ (m, $2 \mathrm{H}), 1.93(\mathrm{dd}, J 14.0$ and $1.5 \mathrm{~Hz}, 1 \mathrm{H}), 2.31(\mathrm{~d}, J 14.0 \mathrm{~Hz}$, $1 \mathrm{H}), 2.35$ (t, J 6.5 Hz, $2 \mathrm{H}), 6.68-6.70$ (m, $1 \mathrm{H}), 6.76$ (td, $J$ 7.5 and $1.5 \mathrm{~Hz}, 1 \mathrm{H}), 6.79(\mathrm{td}, J 7.5$ and $1.5 \mathrm{~Hz}, 1 \mathrm{H}), 6.90$ (dd, J 7.5 and $1.5 \mathrm{~Hz}, 1 \mathrm{H}) .{ }^{13} \mathrm{C} \mathrm{NMR}\left(125 \mathrm{MHz}, \mathrm{C}_{6} \mathrm{D}_{6}\right) \delta$ 24.5, 28.4, 28.5, 29.6, 38.6, 40.1, 42.1, 52.7, 126.2, 126.4, 126.6, 129.5, 134.9, 143.1, 208.0. HRMS (EI) $\mathrm{m} / \mathrm{z}(\%)$ : 214.13562 (74) [214.13577 Calcd. for $\mathrm{C}_{15} \mathrm{H}_{18} \mathrm{O}, \mathrm{M}^{+}$], 199.11010 (66), 181.09578 (19), 157.09092 (100), 141.05952 (54), 129.05886 (49), 115.04248 (29), 91.04068 (13), 77.02362 (7). IR (film) $v_{\max } / \mathrm{cm}^{-1}: 3103$, 2929, 2877, 1712, 1598, 1491, 1446, 1316, 1295, 1244, $1120,763,736$.

4a-Methylspiro-(1,3-dithiane[2:3]-1,2,3,4,4a,9,10,10aoctahydrophenanthrene) (11). To a solution of compound $10(10 \mathrm{mg}, 0.047 \mathrm{mmol})$ and 1,3-propanedithiol $(6 \mu \mathrm{L}$, $0.06 \mathrm{mmol})$ in $\mathrm{CH}_{2} \mathrm{Cl}_{2}(5 \mathrm{~mL})$, kept under argon at $0{ }^{\circ} \mathrm{C}$, was added freshly distilled $\mathrm{BF}_{3} \mathrm{OEt}_{2}(6 \mu \mathrm{L}, 0.048 \mathrm{mmol})$ via syringe. The mixture was warmed to room temperature and stirred for $1 \mathrm{~h}$. The reaction mixture was treated with saturated $\mathrm{NaHCO}_{3}$ solution, and the organic fraction was extracted with $\mathrm{CH}_{2} \mathrm{Cl}_{2}$, the $\mathrm{CH}_{2} \mathrm{Cl}_{2}$ solution was washed with water, dried over $\mathrm{MgSO}_{4}$ and concentrated under reduced pressure. Purification by chromatography on silica gel afforded $13.2 \mathrm{mg}$ (93\%) of compound $\mathbf{1 1}$ as a colorless solid. ${ }^{1} \mathrm{H}$ NMR $\left(500 \mathrm{MHz}, \mathrm{C}_{6} \mathrm{D}_{6}\right) \delta 1.33$ (s, $\left.3 \mathrm{H}\right), 1.63-1.74$ (m, 2 H), 1.78-2.06 (m, 7 H), 2.41-2.49 (m, 2 H), 2.66$2.76(\mathrm{~m}, 4 \mathrm{H}), 2.95$ (ddd, J 17.0, 11.0 and $6.0 \mathrm{~Hz}, 1 \mathrm{H}), 3.02$ (ddd, $J 14.1,11.0$ and $3.0 \mathrm{~Hz}, 1 \mathrm{H}), 7.04(\mathrm{~d}, J 7.0 \mathrm{~Hz}, 1 \mathrm{H})$, $7.08(\mathrm{td}, J 7.0$ and $1.5 \mathrm{~Hz}, 1 \mathrm{H}), 7.13(\mathrm{td}, J 7.0$ and $1.5 \mathrm{~Hz}$, $1 \mathrm{H}), 7.41(\mathrm{~d}, J 7.0 \mathrm{~Hz}, 1 \mathrm{H}) .{ }^{13} \mathrm{C} \mathrm{NMR}\left(75 \mathrm{MHz}, \mathrm{C}_{6} \mathrm{D}_{6}\right) \delta$ 24.3, 25.0, 25.7, 26.5, 26.6, 26.7, 34.3, 35.9, 37.9, 41.2, 49.0, 50.4, 125.5, 126.9, 129.3, 134.6, 143.5. MS (EI) $\mathrm{m} / \mathrm{z}$

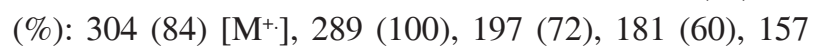
(90), 141 (61), 129 (100), 115 (58), 106 (50), 91 (38), 41 (44).

cis-4a-Methyl-1,2,3,4,4a,10,10a-octahydrophenanthrene (1). To a solution of compound $\mathbf{1 1}(13.2 \mathrm{mg}$, 
$0.043 \mathrm{mmol})$ in ethanol $(5 \mathrm{~mL})$ was added Raney-Ni (100 mg, $1.7 \mathrm{mmol})$. The mixture was kept under reflux during $12 \mathrm{~h}$. After this period the reaction mixture was filtered through a pad of Celite, and the organic fraction was extracted with $\mathrm{CH}_{2} \mathrm{Cl}_{2}$. The $\mathrm{CH}_{2} \mathrm{Cl}_{2}$ solution was washed with water, dried over $\mathrm{Na}_{2} \mathrm{SO}_{4}$ and concentrated under reduced pressure. Purification by chromatography on silica gel afforded $7 \mathrm{mg}(80 \%)$ of compound $\mathbf{1}$ as a colorless oil. ${ }^{1} \mathrm{H}$ NMR (500 MHz, $\mathrm{CDCl}_{3}$ ) $\delta 1.24$ (s, $3 \mathrm{H}, \mathrm{Me}$ ), 1.24-1.25 (m, $1 \mathrm{H}, 2-\mathrm{H}), 1.34-1.43$ [m, $3 \mathrm{H},(1,3,4)-\mathrm{H}], 1.46-1.71$ [m, 5 $\mathrm{H},(1,2,3,10,10 \mathrm{a})-\mathrm{H}], 1.99-2.05$ (m, $1 \mathrm{H}, 10-\mathrm{H}), 2.13-2.17$ (m, $1 \mathrm{H}, 4-\mathrm{H}), 2.76$ (ddd, $J 17.5,6.5$ and $5.0 \mathrm{~Hz}, 1 \mathrm{H}, 9-\mathrm{H}$ ), 2.87 (ddd, $J 17.5,9.0$ and $6.5 \mathrm{~Hz}, 1 \mathrm{H}, 9-\mathrm{H}$ ), 7.04-7.09 [m, 2 $\mathrm{H},(7,8)-\mathrm{H}], 7.12-7.15$ (m, $1 \mathrm{H}, 6-\mathrm{H}), 7.28$ (d, J 8.0 Hz, $1 \mathrm{H}, 5-$ H). ${ }^{13} \mathrm{C} \mathrm{NMR}\left(125 \mathrm{MHz}, \mathrm{CDCl}_{3}\right) \delta 22.9$ (C-2), 24.4 (C-10), 25.1 (C-1), 27.1 (C-9), 28.1 (C-3), 31.7 (Me), 37.5 (C-4a), 38.2 (C-4), 41.2 (C-10a), 125.1 (C-7), 125.8 (C-6), 126.0 (C5), $129.3(\mathrm{C}-8), 136.0\left(\mathrm{C}_{\text {quat }}\right)$. HRMS (EI) $\mathrm{m} / \mathrm{z}(\%): 200.15652$ (37) [200.15650 calcd. for $\mathrm{C}_{15} \mathrm{H}_{20}, \mathrm{M}^{+}$], 185.13450 (100), 157.10363 (35), 143.08707 (32), 129.07359 (27), 117.07365 (34), 91.05856 (11), 69.07265 (7).

\section{Acknowledgments}

The authors are indebted to FAPESP and to the Fonds der Chemischen Industrie for financial support. DCR is grateful to CNPq for a scholarship that enabled her to spend three months in the laboratory of AdM in Göttingen. The authors are grateful to Dr. Burkhard Knieriem, Göttingen, for his careful proofreading of the final manuscript.

\section{References}

1. Koike, L.; Rebouças, L. M. C.; Reis, F. de A. M.; Marsaioli, A. J.; Richnow, H. H.; Michaelis, W.; Org. Geochem. 1992, 18, 851; Lopes, J. A. D.; Neto, E. V. S.; Mello, M. R.; Koike, L.; Marsaioli, A. J.; Reis, F. de A. M.; Chem. Geology 1999, 158, 1; Nascimento, L. R.; Rebouças, L. M. C.; Koike, L.; Reis, F. de A. M.; Soldan, A. L.; Cerqueira, J. R.; Marsaioli, A. J.; Org. Geochem. 1999, 30, 1175; Rodrigues, D. C.; Koike, L.; Reis F. de A. M.; Alves, H. P.; Chang, H. K.; Trindade, L. A.; Marsaioli, A. J.; Org. Geochem. 2000, 31, 1209.

2. Campbell, A. L.; Leader, H. N.; Spencer, C. L.; McChesney, J. D.; J. Org. Chem. 1979, 44, 2746; Gonzalez-Sierra, M.; Leader, H. N.; McChesney, J. D.; J. Org. Chem. 1985, 50, 4450; Sinha, G.; Maji, S. K.; Ghatak, U. R.; Mukherjee, M.; Mukherjee, A. K.; Chakravarty, A. K.; J. Chem. Soc., Perkin Trans I 1983, 2519; Spanevello, R. A.; Gonzales-Sierra, M.; McChesney, J.; Synth. Commun. 1993, 23, 2463.

3. de Meijere, A.; Bräse, S.; J. Organomet. Chem. 1999, 576, 88; Tsuji, J.; Palladium Reagents and Catalysts, Wiley: Chichester, 1995; de Meijere, A.; Meyer, F. E.; Angew. Chem. Int. Ed. Engl. 1994, 33, 2379; Heck, R. F.; Org. React. 1982, 27, 345.

4. Stokker, G. E.; Tetrahedron Lett. 1987, 28, 3179; Amorese, A.; Arcadi, A.; Bernocchi, E.; Cacchi, S.; Cerrini, S.; Fedeli, W.; Ortar, G.; Tetrahedron 1989, 45, 813; Zuber, R.; Carlens, G.; Haag, R.; de Meijere, A.; Synlett 1996, 542; Hagiwara, H.; Eda, Y.; Morohashi, K.; Suzuki, T.; Ando, M.; Ito, N.; Tetrahedron Lett. 1998, 39, 4055.

5. Laschat, S.; Narjes, F.; Overman, L. E.; Tetrahedron 1994, 50, 347.

6. Jeffery, T.; Tetrahedron Lett. 1985, 26, 2667; Jeffery, T.; Tetrahedron 1996, 52, 10113.

7. RI exp. = Relative Retention Index calculated applying the Van den Dool and Kratz equation (van den Dool, H.; Kratz, P. D.; J. Chromatogr. 1963, 11, 463); t = traces. GC-MS-Analyses were carried out using a HP-5990/5970 system equipped with a J\&W Scientific DB-5 fused silica capillary column $(30 \mathrm{~m} \times 0.25 \mathrm{~mm} \times 0.25 \mathrm{~mm})$; column temperatures were programmed from 90 to $300{ }^{\circ} \mathrm{C}$ at $3.5 \%$ min. Helium was used as carrier gas at $1 \mathrm{~mL} / \mathrm{min}$, and SIM detection mode was used.

Received: November 11, 2001

Published on the web: September 6, 2002

FAPESP helped in meeting the publication costs of this article. 